\title{
System Development for Generating Information on the Consequence Influence of Emergency Situations on the Safety of Economic Activities of Enterprises in Ukraine
}

\author{
Viktor Ievdokymov \\ Rector \\ Zhytomyr Polytechnic State University \\ Zhytomyr, Ukraine \\ rector@ztu.edu.ua
}

\author{
Dymytrii Hrytsyshen \\ Dean of the Faculty of Public \\ Administration and Law \\ Zhytomyr Polytechnic State University \\ Zhytomyr, Ukraine \\ gritsishen.do@gmail.com \\ Kateryna Polyak \\ $P h D$ in Economics \\ Zhytomyr Polytechnic State University \\ Zhytomyr, Ukraine \\ fpupdekanat@gmail.com
}

\author{
Tetiana Tarasova* \\ Professor of Finance, Analysis and \\ Insurance \\ Kharkiv State University of food \\ technology and trade \\ Kharkiv, Ukraine \\ paluhtatiana@gmail.com
}

\begin{abstract}
A system for generating information on the consequences of emergencies through the study areas of transformation of accounting is developed. The current status of the organization and the methodology of accounting does not allow reflecting economic activity under the conditions of emergencies in full, and therefore, the information generated by accounting and submitted through the reporting system does not take into account the influence of emergencies advent. Thus, organizational and methodological provisions of an order of display by improving the use of estimates, invoices and double entry are developed to highlight the information on the consequences of emergency. The system of accounting for business processes (acquisition, production, sale) is aimed at the formation of the cost of finished products and other costs associated with the operation of the enterprise and generating information of all its components. The issues of organization and methodology of accounting of economic processes at the enterprise never hold sway, because the innovative development of the economy and technology leads to the transformation of technical processes, which in its turn requires a change in the mechanism of using elements of the accounting method. That is why there is a difficulty in reflection of the consequences of emergencies from the position of influence on the enterprise's production processes. The necessity of using transit accounts is substantiated providing for changing and expanding the mechanism for using the 8th class, whose name is proposed to be replaced with "Transit accounts on demand". The use of the account 82 "Consequences of Emergencies" with the corresponding subaccounts in the context of the costs of the period and corresponding analytical accounts in the context of the types of consequences of emergency situations will make it possible to distinguish them from the totality. In accordance with the above, the procedure for accounting reflection of the consequences of emergencies that relate to production, general production, administrative and marketing costs and other operational costs has been worked out. In partial estimates of the consequences of $\mathrm{ES}$ the choice of valuation methods for certain types of consequences is justified and a multi-level mechanism for allocating general production costs has been developed. The introduction of these provisions into the
\end{abstract}

practice of domestic enterprises allowed providing a set of information requests of internal and external users.

Keywords-Accounting, accounting law, rating, account and records, emergency, risk, risk management.

\section{INTRODUCTION}

The issue of accounting for the consequences of emergencies (further ES) is important enough from the point of generating information on their impact on the economic security of the enterprise and making decisions on its activities by the external and internal user. These issues are extremely important for Ukraine in view of the following statistic data: 1) according to the national reports on the status of technogenic and native safety in Ukraine [6] material losses as a result of emergencies for the period of 2011-2015 reached 1235481 thousand UAH. 2) as a result of the antiterrorist operation in the East of Ukraine - the ES of social manner, the State Budget of Ukraine from 01.07.14. to 01.04 .16 didn't received taxes from enterprises amounting to 49.8 billion UAH. [8]; 3) in Donetsk and Lugansk regions 217 educational facilities were destroyed, 45 - health care establishments, 51 - culture and sports establishments, 81 administrative buildings, 14 trade and 132 industrial facilities for a total amount of 4 billion 788 million UAH.

The current status of the organization and the methodology of accounting does not allow reflecting economic activity under the conditions of emergencies in full, and therefore, the information generated by accounting and submitted through the reporting system does not take into account the influence of emergencies advent.

Having studied the provisions (standards) of accounting in the context of separate objects, it is possible to establish the fact that none of standards provide the impact of emergencies on the change of an object. In particular, it is impossible to follow the changes in the value of non-current and current assets that were lost or damaged as a result of emergency situations in the accounting system; the valuation of the efficiency of economic 
processes and activities does not take into account the entire set of factors, and consequently a decision may be insufficiently provided with information. Under such conditions, the urgency of the research of accounting problems for the consequences of emergencies with the aim of highlighting them and reflecting their impact on the economic security of the enterprise is increasing.

\section{ACTUAL ANALYSIS OF SCIENTIFIC RESEARCHES}

This state of affairs in the theory and practice of accounting is also due to low research activity on the raised problem. In Ukraine, the problems of accounting for the consequences of emergencies are highlighted in papers and thesis research: D.O. Grytsyshen [1, 10] - problem development of ecological and economic consequences of emergency situations; Nastenko M.M. - problems of accounting and control of emergency activities of agricultural enterprises [4].

\section{CRITICAL POINTS IN THE METHODOLOGY OF} ACCOUNTING FOR THE CONSEQUENCES OF EMERGENCIES

The system of accounting for business processes (acquisition, production, sale) is aimed at the formation of the cost of finished products and other costs associated with the operation of the enterprise and generating information of all its components. The issues of organization and methodology of accounting of economic processes at the enterprise never hold sway, because the innovative development of the economy and technology leads to the transformation of technical processes, which in its turn requires a change in the mechanism of using elements of the accounting method. That is why there is a difficulty in reflection of the consequences of emergencies from the position of influence on the enterprise's production processes.

Update provisions of the organization and methods of accounting do not allow generating high-quality information of the consequences of emergencies in the context of economic processes. As a result, the user receives general information on which he cannot understand the cause and effect relationships in changing of the features that characterize the economic security of the enterprise. But this problem is important today for Ukraine in modern economic and political realities, but accounting science is understudied by its representatives.

To develop the organizational and methodological provisions for the accounting of economic processes under the conditions of emergencies, we proceed away from the classical procedure sequence of using elements of the accounting method, namely: documentation and inventory, valuation and calculation, accounts and double entry, balance and reporting. This is due to the fact that, first of all, it is worth highlighting the basic query of users about the impact of ES on the production. Thus, providing request occurs through the balance sheet ratios (elements of the method: balance and reporting), which are formed due to the reflection on the accounts (method elements: accounts and double entry) according to the correspond estimation (method elements: valuation and calculation), which is determined by the basic document.

Thus, we propose inverse to the formation of organizational and methodological provisions for accounting of the production process under the conditions of emergencies: from reporting to the primary document. This will make it possible to approach the accounting mapping in an integrated manner and solve a number of problems of generating information necessary for making managerial decisions. It should be noted that the production process is directly related to such issue as cost, which is subsequently taken into account in calculating the fundamentals that characterize the financial condition and economic potential of the enterprise. Thus, we implement the development of directions for the accounting method elements for the specified object as a part of influence on a set of fundamentals.

We believe that the financial statements, being the main information source for the implementation of an analytical assessment of the financial situation and economic strength of an enterprise, should provide a set of information of all factors of influence on the resulting issues, including data that characterizes the production process. Therefore, we suggest putting forward the following requirements for financial statements, which will provide an opportunity to carry out not only the calculation of analytical indices, but also to factorize to establish cause and effect relationships, in particular those caused by emergencies:

financial statements should contain information on the increase of production costs and, accordingly, the cost of finished products that arose as a result of emergencies. Such information may be found in the notes to the annual financial statements, both in tabular and description forms indicating the specific case of the ES;

it is worth reporting on measures to eliminate or prevent emergencies for the purposes of assessing the company's response to emergencies. It gives an opportunity to the user, a potential investor in particular, to estimate the probability of such situations occurring in future and, accordingly, to make a positive or negative investment decision;

in reporting, including the statement of financial results (Statement of Comprehensive Income), it is necessary to submit information on the consequences of emergencies, their economic estimates in particular, measures for overcoming and eliminating the consequences of emergencies. This is possible through the allocation of individual expenditure items or composite expenditure items.

The way out of this situation is seen in the expansion of the structure of financial reporting forms, and its content is carried out in the way of opening a transit account that would generate relevant information. In this section, attention is paid directly to the process of generating information by elements of the accounting method: documentation and inventory, valuation and calculation, accounts and double entry.

The formation of the information space and its transformation in accordance with changes in economic realities cannot occur without a meaningful and formal procedure of using accounting method elements. Despite the fact that in the accounting system all aspects of the economic activity of the enterprise must be reflected, the current accounting legislation does not allow for the reflection of the consequences of ES and their impact on the resulting data contained in the financial statements.

The motions of the authors in papers [1] on highlighting the consequences of emergencies on a separate sub-account 978 "Expenditures from ES" that actually transfers them to other expenses are still relevant. However, these motions do not allow to form a complex system, because there is no connection with costs in terms of types of activities (operational, financial, investment), which is quite logical. This approach allows us to 
distinguish the consequences of ES from other objects of accounting and allows us follow the cause and effect relationships in the change of economic data. In addition, all information is put aside of the total set of indicators of economic activity of the enterprise. However, when forming information exclusively in this account, it is not possible to determine the influence on the cost of finished products, and in future, on the profitability ratio of the enterprise. To solve this problem is possible only through a change in the current approach to the structure of the chart of accounts.

The impossibility of applying this account for all consequences of emergencies is due to the fact that, for example, stoppage in production leads to costs associated with downtime, so they should be included in production costs; damage of the cargo during transportation as a result of the incident should increase the cost of sales expenses; the use of auxiliary production services (repair facilities) for renovation works also increases the cost of general production expenses. There are too many such examples in the enterprise; it depends on the specifics of the enterprise's activity, the type and characteristics of ES and their consequences as well as. That is why, the need for other approaches to determine the consequences of ES along with the simultaneous use of the sub-account mentioned above.

It is necessary to use the mentioned account for reflection of the consequences of emergencies that cannot be identified by a separate business process and the relevant type of operating expenses. Analytical data sheet for them should be based on the following analytical sections:

the first section of analytics in the context of the following groups of expenditures that characterize the totality of economic operations carried out by the enterprise under emergency conditions: 978.1. - "Costs and expenses as a result of emergencies"; 978.2. - "Expenses related to rectification of the consequences of emergencies"; 978.3. - "Other expenses related to emergencies";

the second level of analytics that characterizes costs and losses as a result of emergency situations in depends on their possible consequences: 978.1.1. - "Cost of noncurrent assets loss"; 978.1.2 - "Decrease in the value of non-current assets as a result of ES"; 978.1.3. - "Cost of lost current assets"; 978.1.4. "Obligations in respect to third parties as a result of emergencies"; 978.1.5. - "State responsibilities as a Result of Emergencies"; 978.1.6. - "Expenses related to the rectification of the consequences of emergencies"; 978.1.7. - "Other expenses related to the consequences of emergency situations". As to the costs associated with the estimation of the consequences of emergencies, they should be further distributed according to the types of work that will be feasible to overcome them;

the third level of analytics should be opened to reflect costs in the context of cost elements (material costs, labor costs, social costs (unified social tax), amortization, and other expenses).

The organization of analytical accounting for these sections will give an opportunity to carry out economic analysis of the economic activities of enterprises in three main directions: firstly, the influence of the consequences of emergencies on the financial condition and economic strength of the enterprise; secondly, performance valuation of measures of prevention and control of the consequences of emergencies; thirdly, performance valuation of management under the conditions of emergency situations.
More difficult problem is an issue of allocating costs related to the consequences of emergencies that are a part of production costs (Accounts 23 "Production" and 91 "General Production Expenses") or periodic costs, i.e. administrative expenses (Account 92), sales costs (Account 93), other operating loss (Account 94). The formation of analytical accounting for these accounts is unreasonable according to that such information cannot show all the properties of this or that object. That is why in this situation we propose to use the transit account approach according to the example of costs for the elements displayed on the accounts of the 8th class "Expenses by Elements".

\section{TRANSFORMATION OF ACCOUNTING SYSTEM}

To ensure the process of separating the consequences of emergencies from operating expenses, we propose to use the accounts of the 8th class that is possible under the change in its structure and the order of their use. In particular, there has been a long discussion in the academic circles about the use of accounts of this particular class not related to cost elements for the purpose of expanding the information space for managing the economic activities of an enterprise. But, the researchers' proposals were much more determined by the introduction of a new account that corresponded to the object of research without justifying the need for changing the functionality of the entire class of accounts. Usually this class of accounts was used to identify the consequences of the impact of risks on individual objects of accounting and the formation of information about them in financial statements. However, this stand is mistaken without changing the assignment of the accounts by the content and form.

To avoid this methodological error and to highlight the consequences of the emergencies, we propose to change the mechanism of using accounts of the 8th class due to a change in its name and structure and the order of reflection. In particular, we suggest the following procedure for using the specified section:

Firstly, the change of the name of the 8th class from "Expenses by Elements" to "Transit Accounts on Demand";

Secondly, to expand the contribution of accounts of the 8th class "Transit Accounts on Demand", taking into account the costs of elements, consequences of emergencies and riskoriented operations;

Thirdly, to develop a mechanism for using accounts of the 8th class "Transit Accounts on Demand" by proposing changes to the provisions of the Instruction on the implementation of the chart of accounts.

The following structure of this section of the Chart of Accounts taking into consideration the directions of analytical accounting (Figure 1) with the purpose of forming the above is suggested.

This approach to the structure of the 8th class of accounts of accounting will allow to separate the consequences of ES, as well as other mapping objects, is significant for management and decision-making by internal and external users. In particular, it is possible to expand the data of financial statements in the part of financial results report (Statement of Comprehensive Income) and notes to the annual financial statements. 


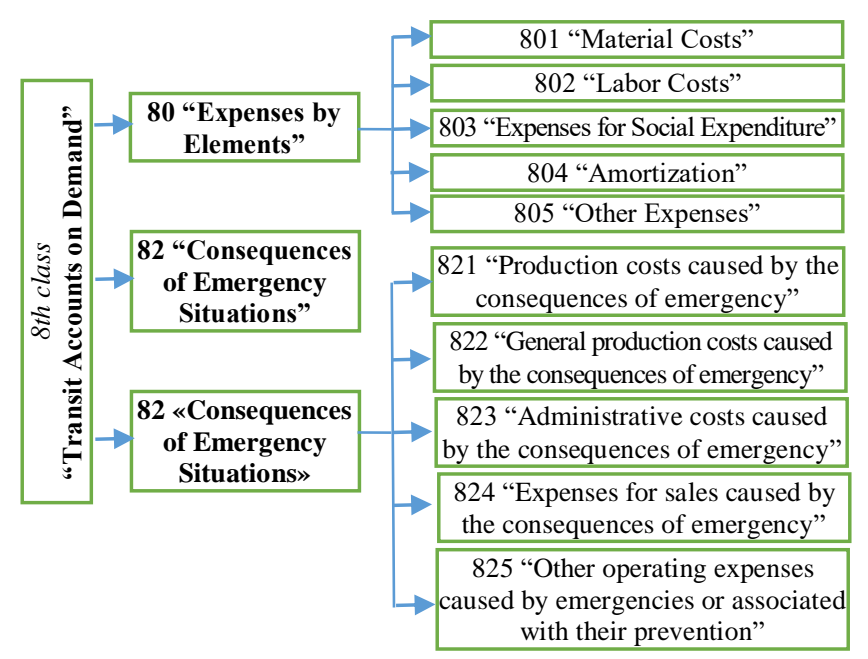

Fig. 1. Structure of the 8th class of the Chart of Accounts "Transit Accounts on Demand"

To determine the mechanism for the formation and use of these accounts, we propose the following changes in the instructions for the implementation of the chart of accounts:

"Accounts of this class are intended to summarize information on accounting objects that should be separated from the total set of economic activities of the enterprise upon request during the reporting period".

Objects that are reflected in the accounts of the specified class must be valued, which can be reliably determined and simultaneously displayed on the balance sheet accounts and income accounts, expenditure and financial results accounts.

Accounts of this class are considered: operating expenses for the following elements of costs: material costs, labor costs, deductions for social activities, amortization and other operating expenses; risk-oriented operations, which are grouped by types of risk and can lead to both income and expenses of the enterprise; consequences of ES, which cause an increase in the following costs: production costs; general production costs, administrative costs, sales costs, other operating expenses; other objects related to which there is a need for allocation from the totality on request.

Further in the specified instruction it is necessary to determine the procedure of accounting reflection for each account and subaccounts shown in Tab.2.5. As to the costs of the elements, we propose to use the current approach defined in the instruction with the corresponding changes in the sub-account code numbers proposed for the Account 80 "Expenses by Elements" (801 "Material Costs", 802 "Labor Costs", 803 "Expenses for Social Expenditure", 804 "Amortization”, 805 "Other Expenses").

The normative fixing of the provisions on the reflection of the consequences of the ES on the Account 82 will answer the main provisions of accounting that we propose to develop in the context of the elements of the method: double entry, valuation, documentation. To ensure full coverage of the consequences of emergencies in the information management space of economic activities, we suggest reflecting the economic operations in details through the organization of analytical accounting. Sections and groupings of information of the consequences of ES are proposed to be carried out according to the following analytical accounts (Table 1). In particular, such approach is relevant for such researched enterprises as CJSC "Novokramatorsk Machine-
Building Plant", CJSC “Korosten Plant of MDF” and Ukrainian Holding Saw Company, while studying the economic activity, the properties and content of the objects associated with the consequences of the emergency were established.

TABLE I. ANALYTIC SECTIONS ON ACCOUNT 82 "CONSEQUENCES OF EMERGENCY SITUATIONS"

\begin{tabular}{|c|c|c|c|c|c|}
\hline \multicolumn{2}{|c|}{ Sub-account } & \multicolumn{2}{|c|}{ Analytics of the $1^{\text {st }}$ level } & \multicolumn{2}{|c|}{$\begin{array}{c}\text { Analytics of the } 2^{\text {nd }} \\
\text { level }\end{array}$} \\
\hline Code & Name & Code & Name & Code & Name \\
\hline 1 & 2 & 3 & 4 & 5 & 6 \\
\hline \multirow[t]{4}{*}{821} & \multirow{4}{*}{$\begin{array}{l}\text { Production } \\
\text { costs caused } \\
\text { by the } \\
\text { consequences } \\
\text { of emergency }\end{array}$} & 821.1 & $\begin{array}{ll}\text { Stoppage } \\
\text { production }\end{array}$ & \multirow{4}{*}{$\begin{array}{l}821.1(2, \\
3,4) .1 \\
(2,3,4, \\
5)\end{array}$} & \multirow[t]{4}{*}{$\begin{array}{l}\text { By cost } \\
\text { element }\end{array}$} \\
\hline & & 821.2 & $\begin{array}{l}\text { Waste } \\
\text { Management }\end{array}$ & & \\
\hline & & 821.3 & $\begin{array}{l}\text { Defects } \\
\text { management }\end{array}$ & & \\
\hline & & 821.4 & $\begin{array}{l}\text { Other production } \\
\text { costs }\end{array}$ & & \\
\hline \multirow[t]{4}{*}{822} & \multirow{4}{*}{$\begin{array}{l}\text { General } \\
\text { production } \\
\text { costs caused } \\
\text { by the } \\
\text { consequences } \\
\text { of emergency }\end{array}$} & 822.1 & $\begin{array}{l}\text { Stoppage in } \\
\text { production }\end{array}$ & \multirow{4}{*}{$\begin{array}{l}822.1 \\
(2,3,4, \\
5) .1 \quad(2, \\
3,4,5)\end{array}$} & \multirow[t]{4}{*}{$\begin{array}{l}\text { By cost } \\
\text { element }\end{array}$} \\
\hline & & 822.2 & $\begin{array}{l}\text { Waste } \\
\text { Management }\end{array}$ & & \\
\hline & & 822.3 & $\begin{array}{l}\text { Defects } \\
\text { management }\end{array}$ & & \\
\hline & & 822.4 & $\begin{array}{l}\text { Other production } \\
\text { costs }\end{array}$ & & \\
\hline \multirow[t]{4}{*}{823} & \multirow{4}{*}{$\begin{array}{l}\text { Administrative } \\
\text { costs caused } \\
\text { by the } \\
\text { consequences } \\
\text { of emergency }\end{array}$} & 823.1 & $\mathrm{~T} \& \mathrm{E}$ & \multirow{4}{*}{\multicolumn{2}{|c|}{$\begin{array}{c}\text { By information } \\
\text { request }\end{array}$}} \\
\hline & & 823.2 & $\begin{array}{l}\text { Negotiated } \\
\text { expenses }\end{array}$ & & \\
\hline & & 823.3 & $\begin{array}{l}\text { Unpredictable } \\
\text { obligations }\end{array}$ & & \\
\hline & & 823.4 & Other expenses & & \\
\hline \multirow[t]{3}{*}{824} & \multirow{3}{*}{$\begin{array}{l}\text { Expenses for } \\
\text { sales caused } \\
\text { by the } \\
\text { consequences } \\
\text { of emergency }\end{array}$} & 824.1 & $\begin{array}{l}\text { Expenses related } \\
\text { to the storage } \\
\text { process }\end{array}$ & \multirow[t]{3}{*}{$\begin{array}{l}824 \cdot 1(2, \\
3) .1 \quad(2 \\
3,4,5)\end{array}$} & \multirow[t]{3}{*}{$\begin{array}{l}\text { By cos } \\
\text { element }\end{array}$} \\
\hline & & 824.2 & $\begin{array}{l}\text { Costs associated } \\
\text { with the } \\
\text { transportation } \\
\text { process }\end{array}$ & & \\
\hline & & 824.3 & Other expenses & & \\
\hline \multirow[t]{4}{*}{825} & \multirow{4}{*}{$\begin{array}{l}\text { Other } \\
\text { operating } \\
\text { expenses } \\
\text { caused by } \\
\text { emergencies } \\
\text { or associated } \\
\text { with their } \\
\text { prevention }\end{array}$} & 825.1 & $\begin{array}{l}\text { Costs associated } \\
\text { with preventing } \\
\text { the } \\
\text { consequences of } \\
\text { emergencies }\end{array}$ & & \\
\hline & & 825.2 & $\begin{array}{l}\text { Doubtful and } \\
\text { irrevocable debts }\end{array}$ & \multirow{3}{*}{\multicolumn{2}{|c|}{$\begin{array}{c}\text { By information } \\
\text { request }\end{array}$}} \\
\hline & & 825.3 & $\begin{array}{l}\text { Loss from } \\
\text { depreciation of } \\
\text { inventories }\end{array}$ & & \\
\hline & & 825.4 & $\begin{array}{l}\text { Acknowledged } \\
\text { fines, fees, } \\
\text { penalties }\end{array}$ & & \\
\hline
\end{tabular}

\section{NEW ACCOUNTING MECHANISM}

To determine the relationship between such elements of the method as double entry, valuation and calculation, it is worthwhile modeling the process of accounting reflection of the consequences of emergencies using transit accounts (821 "Production Costs Caused by the Consequences of Emergency Situations", 822 "General Production Costs Caused by Consequences of Emergency Situations", 823 "Administrative Costs of Caused by the Consequences of ES", 824 "Sale Expenses Caused by ES", 825 "Other Operating Costs Caused by the Consequences of ES") in the context of production, general production, administrative expenses, sale expenses and other operating expenses. Outlined objects in the context of economic processes of production and sales are presented in Table 2. 
TABLE II. ACCOUNTING PRACTICE OF EMERGENCY CONSEQUENCES*

\begin{tabular}{|c|c|c|c|c|}
\hline \multirow{2}{*}{$\begin{array}{c}\text { Contents of Business } \\
\text { Operation }\end{array}$} & \multicolumn{2}{|c|}{ Correspondence } & \multirow{2}{*}{$\begin{array}{c}\text { Source } \\
\text { Document }\end{array}$} & \multirow{2}{*}{$\begin{array}{c}\text { Characteriza- } \\
\text { tion }\end{array}$} \\
\hline & D-t & C-t & & \\
\hline \multicolumn{5}{|c|}{ Direct operating expenses } \\
\hline \multirow{2}{*}{$\begin{array}{l}\text { Reflects the expenses } \\
\text { associated with } \\
\text { production downtime } \\
\text { (in the context of } \\
\text { elements of costs) }\end{array}$} & 821.1 & \begin{tabular}{|l|}
20,66, \\
65,68 \\
\end{tabular} & \multirow{5}{*}{$\begin{array}{l}\text { Way-bill, Pay } \\
\text { sheet, } \\
\text { Calculation, } \\
\text { invoice }\end{array}$} & \multirow{7}{*}{$\begin{array}{l}\text { In accordance } \\
\text { with the } \\
\text { reflection of } \\
\text { expenses } \\
\text { regulated by } \\
\text { the } \\
\text { Accounting } \\
\text { Regulations } \\
\text { (Standards) } 9 \\
\text { «Expenses» }\end{array}$} \\
\hline & 23 & 821.1 & & \\
\hline \multirow{3}{*}{$\begin{array}{l}\text { Reflects the expenses } \\
\text { associated with start / } \\
\text { recovery of production }\end{array}$} & 821.1 & $20,66,6$ & & \\
\hline & & $5,13,68$ & & \\
\hline & 23,91 & 821.1 & & \\
\hline \multirow{2}{*}{$\begin{array}{l}\text { Reflects the expenses } \\
\text { associated with } \\
\text { treatment of wastes, } \\
\text { formed as a result of } \\
\text { emergency }\end{array}$} & 821.2 & \begin{tabular}{|l|}
$20,66,6$ \\
$5,13,68$ \\
\end{tabular} & \multirow{2}{*}{$\begin{array}{l}\text { Way-bill, Pay } \\
\text { sheet, } \\
\text { Calculation, } \\
\text { bill }\end{array}$} & \\
\hline & 23,91 & 821.2 & & \\
\hline \multirow{2}{*}{$\begin{array}{l}\text { Reflects the defected } \\
\text { goods as a result of } \\
\text { emergency }\end{array}$} & 821.3 & 23 & \multirow{2}{*}{$\begin{array}{l}\text { Defected goods } \\
\text { valuation report }\end{array}$} & \multirow{2}{*}{$\begin{array}{c}\text { At semi- } \\
\text { finished } \\
\text { product cost }\end{array}$} \\
\hline & 24 & 821.3 & & \\
\hline \multirow{2}{*}{$\begin{array}{l}\text { Reflects the expenses } \\
\text { associated } \\
\text { recovery of defected } \\
\text { goods }\end{array}$} & 821.3 & \begin{tabular}{|l|}
$20,66,6$ \\
$5,13,68$ \\
\end{tabular} & \multirow{2}{*}{$\begin{array}{l}\text { Way-bill, Pay } \\
\text { sheet, } \\
\text { Calculation, } \\
\text { invoice } \\
\end{array}$} & \multirow[t]{2}{*}{ Positions: $1-3$} \\
\hline & 23 & 821.3 & & \\
\hline \multicolumn{5}{|c|}{ General production expenses } \\
\hline \multirow{2}{*}{$\begin{array}{l}\text { Formation of general } \\
\text { production expenses is } \\
\text { reflected one-to-one } \\
\text { with the production } \\
\text { expenses, on the } \\
\text { condition that they } \\
\text { can't be identified with } \\
\text { the certain type of } \\
\text { production }\end{array}$} & 822 & \begin{tabular}{|c|}
20,66 \\
65,13 \\
68,23 \\
24 \\
\end{tabular} & \multirow{2}{*}{$\begin{array}{c}\text { Documents } \\
\text { identical to the } \\
\text { ones specified } \\
\text { in the positions } \\
1-5\end{array}$} & \multirow{2}{*}{$\begin{array}{l}\text { Approach } \\
\text { identical to the } \\
\text { one specified } \\
\text { in the } \\
\text { positions 1-5 }\end{array}$} \\
\hline & 91 & 822 & & \\
\hline $\begin{array}{l}\text { Breakdown of the } \\
\text { general production } \\
\text { expenses-associated } \\
\text { with emergency }\end{array}$ & 23 & 91 & $\begin{array}{c}\text { Calculation of } \\
\text { breakdown of } \\
\text { the general } \\
\text { production } \\
\text { expenses } \\
\end{array}$ & $\begin{array}{c}\text { Offered } \\
\text { breakdown } \\
\text { mechanism }\end{array}$ \\
\hline \multicolumn{5}{|c|}{ Administrative expenses } \\
\hline \multirow{2}{*}{$\begin{array}{l}\text { Reflects the } \\
\text { representation expenses } \\
\text { associated with } \\
\text { emergency recovery } \\
\end{array}$} & 823.1 & \begin{tabular}{|l|}
$22,66,6$ \\
$5,68,37$
\end{tabular} & \multirow[t]{2}{*}{$\begin{array}{l}\text { Way-bill, Pay } \\
\text { sheet, Invoice }\end{array}$} & \multirow{6}{*}{$\begin{array}{c}\text { In accordance } \\
\text { with the } \\
\text { reflection of } \\
\text { expenses } \\
\text { regulated by } \\
\text { the } \\
\text { Accounting } \\
\text { Regulations } \\
\text { (Standards) } 9 \\
\text { «Expenses» }\end{array}$} \\
\hline & 92 & 823.1 & & \\
\hline \multirow{2}{*}{$\begin{array}{lr}\text { Reflects the } \\
\text { representation expenses } \\
\begin{array}{ll}\text { associated with } \\
\text { emergency recovery }\end{array}\end{array}$} & 823.2 & $\begin{array}{l}66,65 \\
68,37 \\
\end{array}$ & \multirow[t]{2}{*}{$\begin{array}{l}\text { Pay sheet, } \\
\text { Invoice }\end{array}$} & \\
\hline & 92 & 823.2 & & \\
\hline \multirow[b]{2}{*}{$\begin{array}{l}\text { Reflects the } \\
\text { unpredictable } \\
\text { obligation of the } \\
\text { administrative nature, } \\
\text { associated } \\
\text { emergency } \\
\text { consequences }\end{array}$} & 823.3 & 63,68 & \multirow{2}{*}{$\begin{array}{l}\text { Calculation, } \\
\text { invoice }\end{array}$} & \\
\hline & 92 & 823.3 & & \\
\hline \\
\hline $\begin{array}{l}\text { Reflects the expenses } \\
\text { associated with the }\end{array}$ & 824.1 & \begin{tabular}{|l}
$22,66,6$ \\
$5,68,13$
\end{tabular} & $\begin{array}{l}\text { Way-bill, Pay } \\
\text { sheet, Invoice }\end{array}$ & $\begin{array}{c}\text { In accordance } \\
\text { with the }\end{array}$ \\
\hline $\begin{array}{l}\text { value storage process } \\
\text { recovery or loss of } \\
\text { values in emergency } \\
\text { conditions }\end{array}$ & 93 & 824.1 & & $\begin{array}{c}\text { Accounting } \\
\text { Regulations } \\
\text { (Standards) } 9 \\
\text { «Expenses» }\end{array}$ \\
\hline $\begin{array}{l}\text { Reflects the expenses } \\
\text { associated with the }\end{array}$ & 824.2 & \begin{tabular}{|l|}
22,66 \\
65,68 \\
\end{tabular} & $\begin{array}{l}\text { Way-bill, Pay } \\
\text { sheet, Invoice }\end{array}$ & \\
\hline $\begin{array}{l}\text { transportation of } \\
\text { material values due the } \\
\text { emergency }\end{array}$ & 93 & 824.2 & & \\
\hline & Other & erating & enses & \\
\hline $\begin{array}{l}\text { Reflects the expenses } \\
\text { associated with } \\
\text { emergency prevention }\end{array}$ & 825.1 & $\begin{array}{c}22,66 \\
65,68 \\
13\end{array}$ & $\begin{array}{l}\text { Way-bill, Pay } \\
\text { sheet, Invoice }\end{array}$ & $\begin{array}{l}\text { Accounting } \\
\text { Regulations } \\
\text { (Standards) } 9\end{array}$ \\
\hline & 94 & 825.1 & & «Expenses» \\
\hline
\end{tabular}

*Accounts are presented in Table 1; Names of accounts: 13 - Depreciation of non-current assets; 20 Inventories; 22 - Low-value and quickly wearable items; 23 - Production; 24 - Defect in - Inction: 37 - Settlements with different debtors; 65 - Insurance payments; 66 - Payments to employees; 68 - Settlements for other operations; 91 - General production expenses; 92 Administrative expenses; 93 - Sale expenses; 94 - Other operating expenses.

Organizational and methodological accounting regulations of accounting of emergency consequences resulting in increase in operating activities expenses, which consists of production, general production, administrative expenses, distribution expenses and other operating expenses are suggested. The procedure for accounting reflection through the transit accounts of the 8th Class is prescribed separately for each specified type of expenses that is corresponding to the accounting principles specified in the Law of Ukraine, and also is in agreement with the provisions of National Accounting Regulations (Standards), Accounting Regulations (Standards) and with the instruction for using the chart of accounts.

\section{THE MECHANISM OF DISTRIBUTION OF OVERHEAD COSTS}

As for evaluation of specified objects, the most of them are regulated by the Accounting Regulations (Standards), but there is a problem in the allocation of the general production expenses associated with emergency. The problem resides in determining the type of products for allocation of specified consequences in particular and the determining what basis for allocation should be used. The new arrangements of allocation of the general production expenses in industrial enterprises are proposed in the papers of O.V. Ivaniuta [2], P.O. Kutsyk [3], S.V. Svirko [7]. Scientists have developed new approaches to the formation and allocation of general production expenses, but their propositions are essential under the condition of time-constant operation of the enterprise. Subject to the condition that general production expense were formed as a result of emergency there is a need of their allocation between these types of products, the manufacturing process of which was stopped during the emergency.

TABLE III. MECHANISMS OF FORMATION AND ALLOCATION OF THE GENERAL PRODUCTION EXPENSES, ASSOCIATED WITH EMERGENCY CONSEQUENCES

\begin{tabular}{|c|c|c|c|}
\hline Stage & Characteristic & Calculation & Comments \\
\hline \multicolumn{4}{|c|}{ Formation } \\
\hline $\begin{array}{l}\text { 1. Formation } \\
\text { of general } \\
\text { production } \\
\text { expenses }\end{array}$ & $\begin{array}{l}\text { Settlement of the } \\
\text { amount of general } \\
\text { production expenses } \\
\text { associated with } \\
\text { emergency } \\
\text { consequences }\end{array}$ & $\begin{array}{l}\text { Turnovers between } \\
\text { correspondence: } \\
\text { D } 91 \text { C } 822\end{array}$ & $\begin{array}{l}\text { Is defined } \\
\text { cumulatively for the } \\
\text { account } 822 \text { and } \\
\text { also by the } \\
\text { analytical sections }\end{array}$ \\
\hline \multicolumn{4}{|c|}{ Allocation } \\
\hline $\begin{array}{l}\text { 2. Allocation } \\
\text { between } \\
\text { production } \\
\text { areas } \\
\text { (production } \\
\text { units) }\end{array}$ & $\begin{array}{l}\text { Ther Allocation } \\
\text { between separate } \\
\text { production units } \\
\text { which were stopped } \\
\text { is carried out. Base } \\
\text { of allocation: direct } \\
\text { production expenses } \\
\text { associatedr with } \\
\text { emergency r }\end{array}$ & $\begin{array}{c}\mathrm{k}=\text { emergency } \\
\text { GPE / emergency } \\
\mathrm{DPE} ; \\
\text { emergency GPE of } \\
\text { production unit = } \\
\text { emergency DPE of } \\
\text { production unit * } \mathrm{k}\end{array}$ & \multirow{4}{*}{$\begin{array}{l}\text { emergency GPE - } \\
\text { general production } \\
\text { expenses associated } \\
\text { with emergency; } \\
\text { emergency DPE - } \\
\text { direct production } \\
\text { expenses associated } \\
\text { with emergency; } \\
\text { emergency DPE of } \\
\text { production } \\
\text { unit - direct } \\
\text { production } \\
\text { expenses associated } \\
\text { with emergency in } \\
\text { the production unit; } \\
\text { DME - direct } \\
\text { material expenses } \\
\text { by the type of } \\
\text { products }\end{array}$} \\
\hline \multicolumn{3}{|c|}{ Entry: D 91.x C 91y } & \\
\hline $\begin{array}{l}\text { 3. Allocation } \\
\text { between } \\
\text { type of } \\
\text { products }\end{array}$ & $\begin{array}{l}\text { Allocation between } \\
\text { type of products, } \\
\text { production of which } \\
\text { is associated with } \\
\text { the work of } \\
\text { appropriate } \\
\text { production unit }\end{array}$ & $\begin{array}{l}\mathrm{k}=\text { emergency } \\
\text { GPE } \\
\text { production unit / } \\
\text { DPE; } \\
\text { emergency GPE of } \\
\text { production = DME } \\
\text { of production * } \\
\text { emergency GPE of } \\
\text { production unit }\end{array}$ & \\
\hline \multicolumn{3}{|c|}{ Entry: D 23 C 91x } & \\
\hline
\end{tabular}


To solve the specified problem we conducted a series of calculations on the example of CJSC "Novokramatorsk Machine-Building Plant", which has a sophisticated production structure and uses the process method of cost accounting for the formation of self-cost. There was no possibility to provide digital data in the analysis, because of the fact that the information is not for public use. In a point of fact, the author developed the procedure of allocation of the general production expenses which were formed as a result of emergency, which was implemented at CJSC "Novokramatorsk Machine-Building Plant", and that is shown in Table 3.

Specified provisions of allocation mechanism of the general production expenses associated with the emergency are multilayered and provide allocation both between production areas (production units) and between types of products. Its use allows building multifactor models of the economic production cost analysis for the decision-making management.

Thus, resulting from the study we have developed organizational and methodological accounting regulations of accounting of the consequences of emergencies that involve improving of the arrangements for the use of such method elements as valuation, accounts and double entry. In particular, the chart of accounts expansion and the instructions for its use are proved; analytical accounting procedure for the accounts of the 8th Class (81 "Consequences of the Emergencies"); order of the reflection in bookkeeping accounts related to operating activities expenses; allocation mechanism of the general production expenses is developed. Their use in corporate activities practice and their efficiency in forming of the information space for economic activity management under the conditions of emergencies indicates their effectiveness, practical effect and scientific validity.

\section{CONCLUSIONS}

We developed the organizational and methodological provisions of their accounting reflection that involve improving of the arrangements for the use of such method elements as valuation, accounts and double entry for the purpose of highlighting of information of the consequences of ES. The necessity of using the transit accounts that demonstrated with regard to the bookkeeping accounts, which stipulates changes and expansion of use of the mechanism for 8th Class, whose name is offered to be replaced with "Transit Accounts on Demand". The use of Account 82 "Consequences of Emergencies" with the relevant sub-accounts in view of period expenses and relevant analytical accounts in view of emergency consequences types will allow separating them from the totality. In accordance with the above, the procedure of accounting reflection of the consequences of emergencies associated with the production, general production, administrative expenses, distribution expenses and other operating expenses was developed. In a part of the consequences of ES estimation, the choice of evaluation technique for different types of consequences was proved and multi-level mechanism for allocation of the general production costs was developed. The introduction of these provisions into the practice of domestic enterprises allowed providing a set of information requests of internal and external users.

\section{REFERENCES}

[1] O.V. Kuznjecova et ol., Accounting and information support of economic and ecological safety of waste management system. Zhytomyr, Ukraine: ZhDTU. 2015. p. 180 [in Ukrainian] (references)

[2] O.V. Ivanjuta, "Organizational and methodological provisions for the accounting of general production costs at large industrial enterprises", Problemy teoriji ta metodologhiji bukhghaltersjkogho obliku, kontrolju i analizu: Mizhnarodnyj zbirnyk naukovykh pracj, № 1(28), pp. 133-153, 2014. [in Ukrainian] (references)

[3] P.O. Kucyk and O.M. Chabanjuk, "Generic production costs: the order of formation and distribution", Visnyk Ljvivsjkoji komercijnoji akademiji, № 35, pp. 206-212, 2011. [in Ukrainian] (references)

[4] M.M. Nastenko, "Adaptation of the theory of accounting tools to reflect the extraordinary activity of agricultural enterprises", Zbirnyk naukovykh pracj Podiljsjkogho derzhavnogho aghrarnotekhnichnogho universytetu, Vypusk 17, pp. 234-238, 2009. [in Ukrainian] (references)

[5] M.M. Nastenko and N.M. Gudzenko, "The concept of an emergency and the features of displaying its consequences in accounting", Oblik $i$ finansy APK, №2, pp. 39-41, 2009. [in Ukrainian] (references)

[6] National report on the state of technogenic and natural safety in Ukraine [Online]. Available at: http://undicz.dsns.gov.ua/ua/Nacionalna-dopovid-pro-stantehnogennoyi-ta-prirodnoyi-bezpeki-v-Ukrayini.html. Accessed on: August 10, 2019 [in Ukrainian] (references)

[7] S.V. Svirko, "Accounting aspect of management of generating costs of large industrial enterprises", Problemy teoriji ta metodologhiji bukhghaltersjkogho obliku, kontrolju $i$ analizu, № 2 (29), pp. 172184, 2014. [in Ukrainian] (references)

[8] The price of war. How many taxes have lost the budget through the anti-terrorist organization [Online]. Available at: http://www.epravda.com.ua/publications/2016/08/30/603534/ Accessed on: August 12, 2019 [in Ukrainian] (references)

[9] The price of war: the economic and social consequences of the conflict in the Donbass [Online]. Available at: http://mediarnbo.org/2014/09/17/tsina-viyni-ekonomichni-i-sotsialninaslidki-konfliktu-na-donbasi/. Accessed on: August 10, 2019 [in Ukrainian] (references)

[10] D. Grytsyshen, "The economic and environmental consequences of emergency situations in the system of accounting objects", Economic Annals-XXI. № 7-8(1). pp. 113-118, 2015. [in Ukrainian] (references) 